\title{
Evaluating the thermoresistance of Bacillus cereus strains isolated from wheat flour
}

\author{
Avaliação da resistência térmica de cepas de Bacillus cereus isoladas de farinha de trigo \\ Evaluación de la resistencia térmica de cepas Bacillus cereus aisladas de harina de trigo
}

Received: 04/20/2021 | Reviewed: 04/27/2021 | Accept: 05/06/2021 | Published: 05/19/2021

\author{
Eliandra Mirlei Rossi \\ ORCID: https://orcid.org/0000-0001-6270-9953 \\ Universidade do Oeste de Santa Catarina, Brazil \\ E-mail: eliandra_bio@yahoo.com.br \\ Suelen Caroline Mahl \\ ORCID: https://orcid.org/0000-0002-7959-6294 \\ Universidade do Oeste de Santa Catarina, Brazil \\ E-mail: suca_c.m@hotmail.com \\ Ana Carolina Spaniol \\ ORCID: https://orcid.org/0000-0003-0404-9525 \\ Universidade do Oeste de Santa Catarina, Brazil \\ E-mail: anakarolspaniol@ hotmail.com \\ Jéssica Fernanda Barreto Honorato \\ ORCID: https://orcid.org/0000-0002-1827-0194 \\ Universidade do Oeste de Santa Catarina, Brazil \\ E-mail: jessica.barreto@unoesc.edu.br \\ Tauany Rocha \\ ORCID: https://orcid.org/0000-0003-4087-4215 \\ Universidade do Oeste de Santa Catarina, Brazil \\ E-mail: tauanyrocha@yahoo.com.br
}

\begin{abstract}
Wheat flour is often used to prepare confectionery and baked goods, however, it can be contaminated by aporulating microorganisms contaminated during harvest or improper storage. The aim of this study was to isolate Bacillus cereus strains from different wheat flour brands and to evaluate their thermoresistance in different confectionery products. It was done in order to investigate the risks posed by food prepared with flour contaminated with $B$. cereus to consumers' health. The investigation of B.cereus was realized in five brands of different wheat flours were collected and named $\mathrm{A}$ to $\mathrm{E}$. The isolated strains were subjected to boiling tests in vitro to evaluate their thermoresistance. In addition, confectionery products were prepared with flour contaminated with B. cereus strains. These products were subjected to different cooking and B. cereus strain ATCC $^{\circledR} 30301^{\mathrm{TM}}$ was used as control. Flour brands were contaminated with $B$. cereus; and counts ranged from 0.25 to $1.57 \mathrm{log} \mathrm{CFU} / \mathrm{g}$. The strains presented higher thermoresistance in the confectionery products than in the test conducted in vitro. Based on our results, it was concluded that B. cereus strains are thermoresistant. Moreover, if the flour is contaminated with this bacterium, food products subjected to thermal treatments may remain contaminated. In addition, it is suggested that there is some mechanism (not observed in our study) that could directly influence the thermoresistance of strains found in food.
\end{abstract}

Keywords: Wheat flour; Bacillus cereus; Contamination; Thermoresistance; Food.

\section{Resumo}

A farinha de trigo é frequentemente usada para prepare de produtos de confeitaria e panificados, entretanto, pode estar contaminada por microrganismos esporulados principalemnte durante a colheita ou armazenamento inadequado. $\mathrm{O}$ objetivo deste estudo foi isolar cepas de Bacillus cereus de diferentes marcas de farinha de trigo e avaliar sua termoresistência em diferentes produtos de confeitaria. Isso foi feito com o objetivo de investigar os riscos apresentados por alimentos preparados com farinha contaminada com B. cereus para a saúde dos consumidores. A investigação de $B$. cereus foi realizada em cinco marcas de diferentes farinhas de trigo coletadas e denominadas de A a E. As cepas isoladas foram submetidas a testes de fervura in vitro para avaliação de sua termorresistência. Além disso, produtos de confeitaria foram preparados com farinha contaminada com cepas de B. cereus. Esses produtos foram submetidos a diferentes cozimentos e a cepa de B. cereus ATCC ${ }^{3} 30301$ TM foi usada como controle. Todas as marcas de farinha que estavam contaminadas com B. cereus e as contagens variaram de 0,25 a $1,57 \mathrm{log} \mathrm{CFU} / \mathrm{g}$. As cepas apresentaram maior termoresistência nos produtos de confeitaria do que no teste realizado in vitro. Com base em nossos resultados, concluiu-se que as cepas de B. cereus são termorresistentes e se a farinha estiver contaminada com essa bactéria, os produtos embora sejam submetidos a tratamentos térmicos podem permanecer contaminados. Além disso, sugere-se que exista algum mecanismo (não observado em nosso estudo) que poderia influenciar diretamente na termorresistência das cepas encontradas nos alimentos. 
Palavras-chave: Farinha de trigo; Bacillus cereus; Contaminação; Termoresistência; Alimentos.

\section{Resumen}

La harina de trigo se usa a menudo para preparar productos de repostería y panadería, sin embargo, puede contaminarse con microorganismos esporulados principalmente durante la cosecha o el almacenamiento inadecuado. El objetivo de este estudio fue aislar cepas de Bacillus cereus de diferentes marcas de harina de trigo y evaluar su termorresistencia en diferentes productos de repostería. Esto se hizo con el fin de investigar los riesgos que plantean los alimentos preparados con harina contaminada con B. cereus para la salud de los consumidores. La investigación de B. cereus se llevó a cabo en cinco marcas de diferentes harinas de trigo recolectadas y nombradas de la A a la E. Las cepas aisladas se sometieron a pruebas de ebullición in vitro para evaluar su termorresistencia. Además, se prepararon productos de confitería con harina contaminada con cepas de B. cereus. Estos productos se sometieron a diferentes cocciones y se utilizó como control la cepa de B. cereus ATCC®30301 TM. Todas las marcas de harina que estaban contaminadas con $B$. cereus y los recuentos oscilaron entre 0,25 y $1,57 \log$ UFC / g. Las cepas mostraron una mayor termorresistencia en productos de confitería que en el ensayo realizado in vitro. Con base en nuestros resultados, se concluyó que las cepas de $B$. cereus son termorresistentes y si la harina está contaminada con esta bacteria, los productos, aunque sometidos a tratamientos térmicos, pueden permanecer contaminados. Además, se sugiere que existe un mecanismo (no observado en nuestro estudio) que podría influir directamente en la termorresistencia de las cepas que se encuentran en los alimentos.

Palabras clave: Harina de trigo; Bacillus cereus; Contaminación; Termorresistencia; Comida.

\section{Introduction}

Wheat flour is the main raw material used to make dough-based products; it has high nutritional value and, consequently, is a staple food for the world population (Kucek et al., 2017). Sixty-two percent (62\%) of the flour used as raw material in Brazil in 2017 was destined to the bakery sector, 23\% was added with flour enhancers, $14 \%$ to biscuit flour and $1 \%$ was used in other segments (Abitrigo, 2018). It is widely used by the population as the main component in the dough to be added with other ingredients because it makes the food-production process easier, is easy to be handled and presents stability during storage. (Minguita et al., 2015; Katyal et al., 2015).

The flour production process comprises milling and/or grinding the grain (Triticum aestivum L.) - or other wheat species belonging to genus Triticum - to transform the endosperm into flour; next, the bran is separated from the germ to enable the preparation of higher-quality products (Scheuer et al., 2014). However, the production of farinaceous products has been facing issues such as the contamination with thermoduric and sporulated microorganisms like Bacillus cereus, which can deteriorate the products and pose risks to human health (Senesi and Ghelardi, 2010; Chaves et al., 2011).

This microorganism is a Gram-positive, facultative anaerobic, spore-forming bacterium found in different environments such as soil, vegetation, water and animal hair. This bacterium multiplies at temperatures ranging from 25 to $37^{\circ} \mathrm{C}, \mathrm{pH}$ ranging from 5.0 to 9.3 and water activity ranging from 0.92 to 0.95 . In addition, it may remain viable for long periods in the environment and in food, because of its ability to form spores resistant to severe conditions (Paiva et al., 2009).

The B. cereus is ubiquitous in the environment and can be recovered from food and food materials. It also forms heat resistant spores that are likely to survive the mild heat treatments given to these foods. (Setlow, 2006; Webb et al., 2019). Moreover, spores are extremely dormant and may survive thousands of years in the wet. (Wohlgemuth; Kämpfer, 2014).

Wheat flour can be contaminated with B. cereus at all food production stages - from grain harvesting to its processing into dough and ready-to-eat product. Thus, the development of this bacterium in food products can contribute to the incidence of food-borne diseases (Ferreira, 2003).

B.cereus is often found in dry food, it is associated with outbreaks that take place after the intake of food such as sauces, sausages, soups, oven-baked food, rice, doughs, puddings, milk powder, flours, cereals and salads. B. cereus is the main cause of food poisoning outbreaks caused by contaminated cereals; this bacterium triggers reactions such as vomiting and diarrhea due to the emetic toxin and enterotoxins produced by it during food processing (Faille et al., 2014; Liu et al., 2018). 
Controlling this bacterium in food products is not an easy task due to its ability to produce thermoresistant spores and to adapt to thermally-treated food. This difficulty contributes to their survival and dissemination in the environment, as well as to the contamination of raw materials and post-processing products (Carlin et al., 2010; Abee et al., 2011).

Thus, the aim of the current study was to evaluate the thermoresistance of B. cereus strains isolated from wheat flours, by taking into consideration that this raw material is used to prepare several food products that are subjected to different cooking types. The condition in which B. cereus recorded the highest thermoresistance was also investigated in this study in order to contribute scientific information that can help to control food contamination by this bacterium.

\section{Methodology}

\subsection{Investigating strains of the Bacillus cereus group on wheat flours}

Three samples from each of the five brands of flours (named A, B, C, D and E) were collected and subjected to microorganism counting in order to check whether the flour was contaminated with strains of the B. cereus group. The counting procedure complied with Normative Instruction 62/2003 of the Ministry of Agriculture, Livestock and Food Supply (MAPA). Twenty-five grams (25g) of each sample were aseptically homogenized in 0.1\% peptone water in order to get a 1:10 (and, subsequently, 1: 100) dilution, which was seeded in Petri dishes containing phenol-egg yolk-mannitol-polymyxin B (MYP agar) and incubated at $30 \pm 1^{\circ} \mathrm{C}$ for $48 \mathrm{~h}$.

Colonies surrounded by opaque precipitation halo with rosy background were counted and isolated, since they represented typical colonies of the B. cereus group. Next, staining (Gram staining) and biochemical (nitrate motility and reduction, $\alpha$-hemolysis, tyrosine decomposition, rhizoid growth and presence of crystalline inclusion corpuscles) tests were performed. Results were expressed in colony-forming units per gram (CFU/g).

\subsection{Evaluating the thermoresistance of strains of the Bacillus cereus group.}

To verify the thermoresistance of strains of the Bacillus cereus group was used methodology of Johnson;Nelson; Busta (1982) with adaptations.

Three (3) B. cereus group strains isolated from the investigated wheat flours were selected to evaluate their thermoresistance; and B. cereus ATCC $^{\circledR} 33019^{\mathrm{TM}}$ strain was used as a control.

The thermoresistance of B. cereus was evaluated during the preparation of confectionery products (cake, cream, cupcake and pudding) whose doughs were based on ingredients such as wheat flour, sugar, eggs, milk, margarine and baking powder. All the ingredients were mixed in a plastic vessel; after the doughs showed adequate consistency and growth, they were transferred to a pan in order to be cooked/baked.

The doughs were contaminated with a known number of B. cereus strains and/or spores $\left(10^{6} \mathrm{CFU} / \mathrm{g}\right)$ and homogenized to assure uniform microorganism distribution before they were cooked. The confectionery products, as well as their cooking method, time and temperature, are described in Table 1. 
Table 1. Confectionery product-cooking methods.

\begin{tabular}{ccc}
\hline Confectionery product & Cooking method & Cooking time/temperature \\
\hline Cake & Electric oven & 50 minutes at $180^{\circ} \mathrm{C}$ \\
Cream & Electric oven & 20 minutes at $96^{\circ} \mathrm{C}$ \\
Cupcake & Electric oven & 30 minutes at $180^{\circ} \mathrm{C}$ \\
Pudding & Water bath & 90 minutes at $80^{\circ} \mathrm{C}$ \\
\hline
\end{tabular}

Source: Authors.

Were analysed portions of the food that were used as a negative control (absence of bacteria from the B.cereus group) before being contaminated and as a positive control (presence of bacteria from the B. cereus group) portions of the food after contamination with the test strains.

A digital thermometer used for cooking purposes (model TP-101) was adopted to check whether the oven, water bath and direct-heating temperatures were correct. After the heating/baking process was over, the doughs were covered and kept at room temperature (natural cooling). The analysis was performed in triplicate only after the products were fully cooked, i.e., when they were ready for consumption.

Subsequently, B. cereus strains (ATCC ${ }^{\circledR} 33019$ TM and wild strains isolated from the wheat flours singly) were diluted in sterile water at a concentration of $10^{6} \mathrm{CFU} / \mathrm{ml}$ in a test tube and subjected to test in vitro, when they were subjected to baking in a glass Becker. The strains were subjected to approximately $96^{\circ} \mathrm{C}$ for $0,5,10,15,20,25,30$ and 35 minutes. Then, B. cereus were counted according to the methodology described.

\subsection{Statistical analysis}

The Assistat software version 7.7 (2016) was used in association with Excel 2013 to generate a database to enable the analysis of the Tukey test results ( $\mathrm{p}<0.05)$.

\section{Results and Discussion}

The microbiological analyses showed that all the investigated flours were contaminated with B. cereus group. The recorded amounts ranged from $0.25 \log \mathrm{CFU} / \mathrm{g}$ to $1.57 \log \mathrm{CFU} / \mathrm{g}$; however, they were within the limits $(3.48 \log \mathrm{CFU} / \mathrm{g}$ ) recommended by the National Sanitary Surveillance Agency (Table 2). In addition, there were no statistical differences in counts between the herein investigated brands.

Table 2. Comparison of microbiological evaluation data between wheat flour samples from 5 different brands.

\begin{tabular}{cl}
\hline Brand & Bacillus cereus Group $(\log$ CFU*/g) \\
\hline A & $0.25 \pm 0.66^{\mathrm{a}}$ \\
B & $0.54 \pm 0.93^{\mathrm{a}}$ \\
C & $1.57 \pm 0.92^{\mathrm{a}}$ \\
D & $0.86 \pm 1.14^{\mathrm{a}}$ \\
E & $0.75 \pm 0.97^{\mathrm{a}}$ \\
\hline
\end{tabular}

*CFU (Colony-Forming Unit). Different letters indicate statistical differences between samples ( $\mathrm{p}<0.05)$. Source: Authors. 
The incidence of this bacterium in the evaluated flours corroborated the study by Prado et al. (2005), who found that 5 $(12.5 \%)$ out of 40 cassava flour samples were contaminated with B. cereus.

Souza et al. (2015) recorded different values (from $2.3 \times 10^{2}$ to $1.8 \times 10^{3}$ ) for the incidence of $B$. cereus in cassava flour - unlike our study, which recorded values within the maximum limits recommended by Anvisa (National Health Surveillance Agency), the aforementioned study recorded values above $10^{3}$.

According to Arsenem et al. (2008), values higher than $6 \log$ CFU/g indicate bacterial multiplication; thus, these values represent a risk factor for human health because toxins are produced during B. cereus multiplication in the food. Although the amounts of B. cereus recorded in our study were lower than $6 \log \mathrm{CFU} / \mathrm{g}$, it is worth emphasizing that the contamination is real and that this flour can favor the multiplication of this bacterium at the time it is used and hydrated during food processing.

Other studies, such as the one conducted by Reyes et al. (2007) showed that milk is another food where this bacterium can be found, since 20 out of 63 different B. cereus strains found in 260 pasteurized, UHT and powdered milk samples were able to produce toxins.

Based on the thermoresistance analyses, B. cereus was able to survive after cooking confectionery products such as cake, cream, cupcake and pudding (Table 3).

Table 3. B. cereus counts in confectionery products subjected to thermal treatment.

\begin{tabular}{clc}
\hline Strains & Product & Mean \\
& & * Log CFU/g \\
\hline ATCC 33019 тм & Cake & $4.53 \pm 0.91$ \\
& Cream & $4.69 \pm 0.38$ \\
& Cupcake & $4.57 \pm 0.99$ \\
A & Pudding & $5.77 \pm 0.40$ \\
& Cake & $5.04 \pm 0.92$ \\
& Cream & $5.30 \pm 0.58$ \\
& Cupcake & $5.73 \pm 0.33$ \\
B & Pudding & $5.87 \pm 0.13$ \\
& Cake & $4.35 \pm 0.62$ \\
& Cream & $4.47 \pm 0.47$ \\
& Cupcake & $5.85 \pm 0.36$ \\
& Pudding & $4.25 \pm 0.44$ \\
& Cake & $5.63 \pm 0.08$ \\
& Cream & $5.52 \pm 0.06$ \\
& Cupcake & $5.93 \pm 0.12$ \\
& Pudding & $5.21 \pm 0.09$ \\
\hline
\end{tabular}

*CFU (Colony-Forming Unit). Source: Authors.

Based on Table 4, there was no statistical difference in B. cereus thermoresistance between the tested food products. Therefore, food composition and cooking temperature did not influence the thermoresistance of the tested strains. 
Table 4. Comparison of B. cereus count between confectionery products.

\begin{tabular}{cc}
\hline Confectionery products & Bacillus cereus Group $(\log$ CFU*/g) \\
\hline Cake & $4.76 \mathrm{a}$ \\
Cream & $4.91 \mathrm{a}$ \\
Cupcake & $5.45 \mathrm{a}$ \\
Pudding & $5.18 \mathrm{a}$ \\
\hline * CFU (Colony-Forming Unit). Different letters indicate statistical differences between samples ( $(\mathrm{p}<0.05)$. Source: Authors.
\end{tabular}

Our results were similar Fazzoni et al. (2013) and Sánchez et al. (2014), who found incidence of B. cereus in several foods made from wheat flour. According to the aforementioned studies, the high count of B. cereus may have resulted from the raw material, as well as from poor production, storage and handling conditions.

These food types, besides being able to present the bacterium in its sporulated form, are often stored in unappropriate temperature conditions after their preparation. These conditions favor spore germination and enable the intake of the vegetative form of the bacterium and/or of its toxin (Luu-Thi et al. 2014).

Other studies, such as the one conducted by Rubio and Andres (2015), showed that B. cereus can survive in the food after the cooking process is over and that food storage temperature can directly affect the post-cooking multiplication of this bacterium. The aforementioned author compared white rice to vitaminized rice and found that white rice stored at $10^{\circ} \mathrm{C}$ recorded maximum spore count $2.8 \log \mathrm{CFU} / \mathrm{g}$, whereas vitaminized rice recorded $4.8 \mathrm{log} \mathrm{CFU} / \mathrm{g}$. On the other hand, white rice and vitaminized rice stored at $25^{\circ} \mathrm{C}$ recorded maximum spore count $5.4 \log \mathrm{CFU} / \mathrm{g}$ and $8.4 \log \mathrm{CFU} / \mathrm{g}$, respectively.

Our results corroborate with Eijlander et al. (2011) that spores of Bacillus species can survive stress conditions, for example, heating food. These insufficient inactivation associated with nutrients found in food can contribute the germination of these spores and results in multiplicationn these bacteria, with great risk of food spoilage and food poisoning after consumption.

Moreover, spore properties and germination efficiency are clearly affected by differences in environmental conditions, as for example, the presence or absence of certain nutrients or chemical compounds in the foods, the $\mathrm{pH}$, temperature and time of exposure at high temperatures (Eijlander et al. 2011).

The table 5 presents the results of thermoresistance comparison between the tested B. cereus strains. Wild strains A and C showed higher thermoresistance than the ATCC strain in the tested food products.

Table 5. Comparison of thermoresistance between B. cereus strains tested in different confectionery products.

\begin{tabular}{cc}
\hline Strains & Bacillus cereus Group(Log CFU*/g) \\
\hline ATCC $^{\circledR 3} 3019^{\mathrm{TM}}$ & $4.52 \mathrm{~b}$ \\
A & $5.41 \mathrm{a}$ \\
B & $5.04 \mathrm{ab}$ \\
C & $5.33 \mathrm{a}$ \\
\hline
\end{tabular}

* CFU (Colony-Forming Unit). Different letters indicate statistical differences between samples $(\mathrm{p}<0.05)$. Source: authors.

In light of the foregoing, it is suspected that this bacterium has adapted to flour storage media, since it is able to survive in products presenting low water activity for long periods. Consequently, when the flour is used to make food, the dormant spores are hydrated that associated with the new environmental conditions $(\mathrm{pH}$, temperature, osmotic pressure, 
nutrients) start forming new cells already adapted to the new ready-to-eat food (Van der Auwera, et al., 2007; Hoon et al. 2010; Mckenney et al. 2013).

On the other hand, results of the test conducted in vitro showed that vegetative cells were eliminated during the first 5 minutes of the cooking process in sterile water. However, boiling in vitro was unable to destroy the spores, which survived (2.0 $\log \mathrm{CFU} / \mathrm{mL}$, on average) up to 35 boiling minutes (Figure 1).

Figure 1. Comparison between B. cereus cooking times in test conducted in vitro.

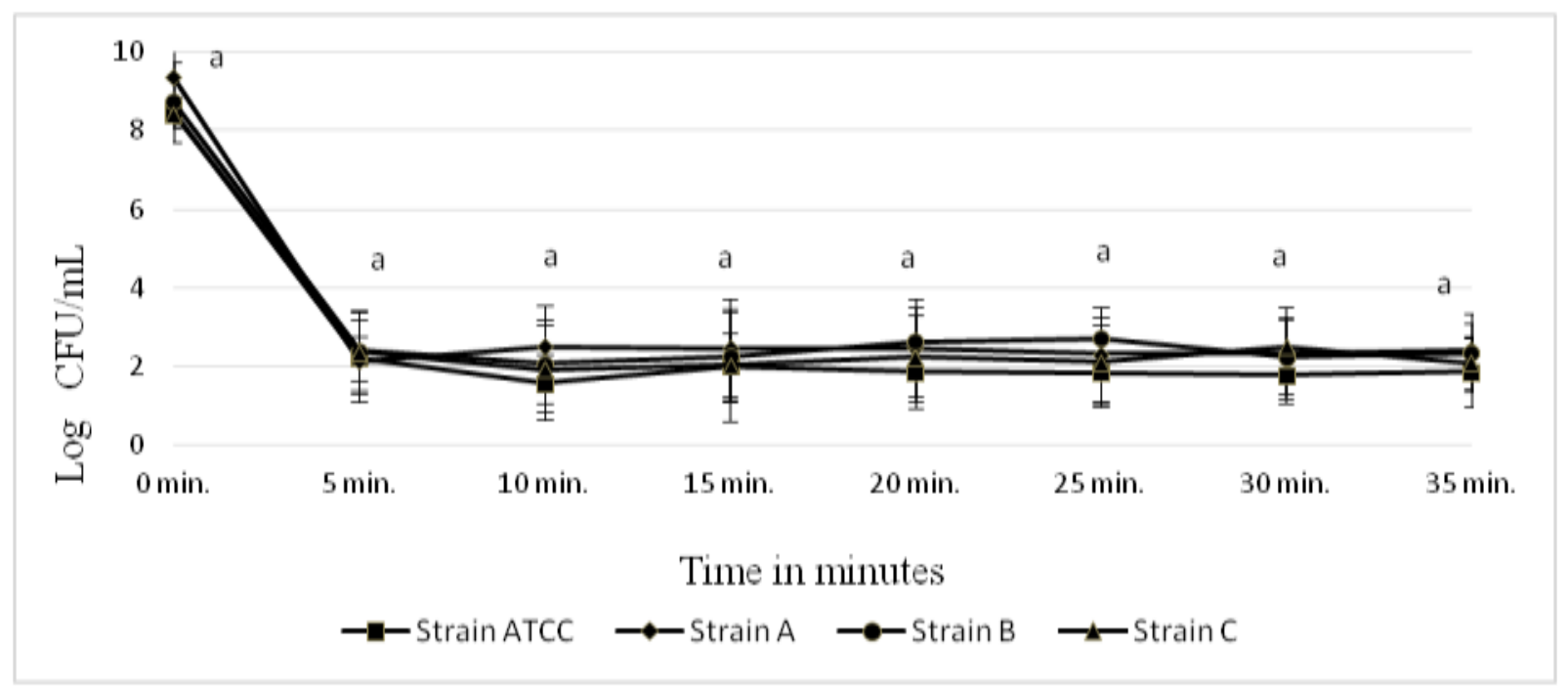

Different letters indicate statistical differences between strains $(\mathrm{p}<0.05)$. Source: authors.

Our results corroborate the study by Rossi et al. (2012), who stated that boiling is a heat treatment capable of destroying only vegetative cells because the water-boiling temperature does not exceed $100^{\circ} \mathrm{C}$.

Results of all boiling times were statistically different from those of the initial time (before boiling) in the test conducted in vitro. As it was previously mentioned, data showed that vegetative cells were destroyed and only the spores remained after the first five boiling minutes, since they were able to resist up to 35 boiling minutes (Table 6 ).

Table 6. Mean LogCFU/ml of the test conducted in vitro thermoresistance evaluation of B.cereus strains (ATCC ${ }^{\circledR} 33019$ TM and wild strains isolated from the wheat flours) tested separately.

\begin{tabular}{lc}
\hline \multicolumn{1}{c}{ Time } & $\begin{array}{c}\text { Mean } \\
\text { LogCFU/ml }\end{array}$ \\
\hline Zero minutes & $8.83 \mathrm{a}$ \\
Five minutes & $2.25 \mathrm{~b}$ \\
Ten minutes & $1.99 \mathrm{~b}$ \\
Fifteen minutes & $2.21 \mathrm{~b}$ \\
Twenty minutes & $2.23 \mathrm{~b}$ \\
Twenty-five minutes & $2.29 \mathrm{~b}$ \\
Thirty minutes & $2.20 \mathrm{~b}$ \\
Thirty-five minutes & $2.23 \mathrm{~b}$
\end{tabular}


Results recorded by Bradshaw et al. (1975) and Dufrenne et al. (1995) were similar to ours. The aforementioned studies evaluated several B. cereus spore strains and found that one strain was thermoresistant for 2.90 minutes at $90^{\circ} \mathrm{C}$, whereas the other psychrotrophic B. cereus strains were thermoresistant from 2.8 to 9.2 minutes at $90^{\circ} \mathrm{C}$. Moreover, Wang (1994) analyzed the kinetic parameters of thermal resistance in the main sporulated organisms found in fluid milk samples, among them, B. cereus, which recorded thermoresistance for 3.8 minutes at $35.9^{\circ} \mathrm{C}$.

Based on figure 1, there was no statistical difference in thermoresistance in vitro between the tested $B$. cereus strains.

B. cereus thermoresistance in vitro has been investigated by several researchers such as Den Besten et al. (2010), who showed that the boiling efficiency in destroying this bacterium may vary if one takes into consideration the number of vegetative cells and spores in the sample: the larger the number of spores, the higher the thermoresistance. The aforementioned authors concluded that the number of $B$. cereus vegetative cells decreased after 9 minutes at $44.5^{\circ} \mathrm{C}$, whereas the number of $B$. cereus in the stationary phase did not decrease during 15 minutes at $44^{\circ} \mathrm{C}$; they were the specimens most resistant to heat.

Other studies, such as the one conducted by Valerio et al. (2012), showed that the initial contamination of semolina (durum wheat) used for Algerian couscous production was $20 \mathrm{CFU} / \mathrm{g}$ of $\mathrm{B}$. cereus spores after heat treatment at $80^{\circ} \mathrm{C}$ for 10 minutes.

According to data described in Tables 5 and 6, the herein tested B. cereus strains recorded higher thermoresistance $($ mean $=5.0 \log \mathrm{CFU} / \mathrm{ml})$ in confectionery products when compared with the results of the test conducted in vitro $($ mean $=2.0$ $\log \mathrm{CFU} / \mathrm{ml})$.

The higher thermoresistance of B. cereus in the analyzed food can be explained by the fact that these products enable higher thermoresistance, thus assuring additional heat protection. In addition, food can also work as good nutritional medium for this bacterium, since this medium enables favorable enzyme and spore production conditions (Sánchez, 2016).

It is known that genus Bacillus comprises resistant microorganisms capable of adapting to extreme environmental conditions. These microorganisms actively grow at temperatures ranging from 25 to $37^{\circ} \mathrm{C}$, besides presenting psychotropic properties depending on their ability to grow in food stored at temperatures ranging from 3 to $75^{\circ} \mathrm{C}$ (Paiva et al., 2009).

On the other hand, growth conditions also affect their thermoresistance. Lound et al. (2017) believe that such resistance is associated with the low water content inside the cell. These researchers saw that heat induces intense water molecule vibration and, consequently, breaks the disulfide and hydrogen bonds of the intracellular proteins. However, this vibration does not happen in vegetative cells due to limited water availability, which, in its turn, protects cellular proteins from denaturizing at high temperatures. Therefore, incorrect food storage temperature, water activity, $\mathrm{pH}$ and food composition were probably the factors that most contributed to Bacillus cereus thermoresistance during the cooking process.

However this study may have been limited by its structure because the experiment in vitro was conducted only in wet conditions and water conducts heat better. Although the food tested has water, we believe the in vitro results may have been better because water directly conducted heat and contributed to cell death.

Thus, our results can contribute to the development of new research to a deeper understanding of the mechanisms involved in spore resistance, adaptation and killing (and heterogeneity there-in) may lead to improved models for spore behavior prediction.

In addition, studies can be developed to verify the spread of B.cereus in environments such as bakeries or bakery industries, because according to Garcia et al. (2019) flour has a particular importance in the dissemination of fungal spores because they could disperse in the processing air during food processing. 


\section{Conclusion}

Results of the current study allowed us to conclude that flours may be contaminated with B. cereus, and that this bacterium can survive cooking and remains in ready-to-eat food products. Facts that may lead to health issues if the flour is not properly stored. Consequently, if the flour is contaminated, the food to be prepared with this ingredient can also be contaminated by this pathogen, even if it is subjected to different heat treatments.

In addition, food composition can provide better heat protection for B. cereus, since this bacterium presented higher thermoresistance in food than in tests conducted in vitro. This outcome suggests that there are some mechanisms (not observed in our study) that could directly influence the thermoresistance of the strains found in food.

Thus, we suggest that news research be made to verify the mechanisms of B.cereus thermoresistance in foods.

\section{References}

Abee, T., Groot, M. N., Tempelaars, M., Zwietering, M., Moezelaar, R., \& Voort, M. V. D. (2011). Germination and outgrowth of spores of Bacillus cereus group members: diversity and role of germinant receptors. Food Microbiology; 28(2): 199-208.

Arsenem, L. P. S., Fagerlund, A., \& Granum, P. E. (2008). From soil to gut: Bacillus cereus and its food poisoning toxins. Microbiological Reviews 32:579606.

Associação Brasileira da Indústria do Trigo - Abitrigo. Sobre o Trigo: O que é o trigo. (2018).

Bradshaw, J. G., Peeler, J. T., \& Twedt, R. M. (1975). Heat resistence of ileal loop reactive Bacillus cereus strains isolated from commercially canned food. Applied Microbiology 30(6): 943-945.

Brasil. Ministério da Agricultura, Pecuária e Abastecimento. Instrução Normativa n 62 , de 26 de agosto de 2003. Oficializa os Métodos Analíticos Oficiais para Análises Microbiológicas para Controle de Produtos de Origem Animal e Água. Diário Oficial da República Federativa do Brasil, Brasília, $18 / 09 / 2003$.

Brasil. Ministério da Saúde. Agência Nacional de Vigilância Sanitária. 2001. Resolução RDC n. 12, de 02 de janeiro de 2001. Regulamento Técnico sobre os padrões microbiológicos para alimentos.

Carlin, F., Brillard, J., Broussolle, V., Clavel, T., Duport, C., Jobin, M., \& Guinebretière, M. H, Auger S, Sorokine A, Nguyen-Thé C (2010). Adaptation of Bacillus cereus, an ubiquitous worldwide-distributed foodborne pathogen, to a changing environment. Food Research International, 43(7):1885-1894.

Chaves, J. Q., Pires, E. S., \& Vivoni, A. M. (2011). Genetic diversity, antimicrobial resistance and toxigenic profiles of Bacillus cereus isolated from food in Brazil over three decades. International Journal of Food Microbiology, 147(1):12-16.

Chen, L., Coolbear, T., \& Daniel, R. M. (2004). Characteristics of proteinases and lipases produced by seven Bacillus sp isolated from milk powder production lines. International Dairy Journal, 14:495- 504.

Den Besten, H. M. W., Van Der Mark, E. J., Hensen, L., Abee, T., \& Zwietering, M. H (2010). Quantification of the effect of culturing temperature on saltinduced heat resistance of Bacillus species. Applied and Environmental Microbiology, 76(13): 4286-4292.

Dufrenne, J., Bijwaard, M., Giffel, M., Beumer, R., \& Notermans, S. (1995). Characteristics of some psychrotrophics Bacillus cereus isolates. International Journal of Food Microbiology, 27: 175-183.

Eijlander, R. T., Abee, T., \& Kuipers, O. P. (2011). Bacterial spores in food: how phenotypic variability complicates prediction of spore properties and bacterial behavior. Current Opinion in Biotechnology, 22 (2): 180-186.

Faille, C., Bénézech, T., Midelet-Bourdin, G., Lequette, Y., Clarisse, M., Ronse, G., Ronse, A., \& Slomianny, C. (2014). Sporulation of Bacillus spp. within biofilms: A potential source of contamination in food processing environments. Food Microbiology, 40: 64-74.

Fazzioni, F. D. B., et al (2013). Microbiological evaluation of bakery products and risks to consumer health. Alimentos e Nutrição Araraquara, 24(2): 159164.

Ferreira, R. A. (2003). Trigo: o alimento mais produzido no mundo. Nut. Brasil, 2(1): 45-52.

Garcia, M. V., et al (2019). Incidence of spoilage fungi in the air of bakeries with different hygienic status. International Journal of Food Microbiology, 290: $254-261$

Johnson, K. M., et al (1982). Germination and Heat Resistance of Bacillus cereus Spores from Strains Associated with Diarrheal and Emetic Food-Borne Illnesses. Journal of Food Science, 47: 1268-1271.

Hoon, M. J. L., et al (2010). Hierarchical Evolution of the Bacterial Sporulation Network. Current Biology, 20(17): R735-R745.

Katyal, M., et al (2015). Diversity in quality traits amongst Indian wheat varieties I: Flour and protein characteristics. Food Chemistry, 194: 337-344.

Kucek, L. K. et al. (2017). Evaluation of wheat and emmer varieties for artisanal baking, pasta making, and sensory quality. Journal of Cereal Science, 74: 1927. 
Research, Society and Development, v. 10, n. 6, e2510615268, 2021

(CC BY 4.0) | ISSN 2525-3409 | DOI: http://dx.doi.org/10.33448/rsd-v10i6.15268

Liu, S., et al (2018). Enterococcus faecium as a Salmonella surrogate in the thermal processing of wheat flour: Influence of water activity at high temperatures. Food Microbiology, 74: 92-99.

Lound, L., et al. (2017). Resistencia térmica de Salmonella. Efecto del pH y la atividade del agua. Ciencia, Docencia y Tecnología-Suplemento, 7(7): 01-17.

Luu-Thi, H., et al (2014). Thermal inactivation parameters of spores from different phylogenetic groups of Bacillus cereus. International Journal of Food Microbiology, 189: 183-188.

Mckenney, P. T., et al (2013). The Bacillus subtilis endospore: assembly and functions of the multilayered coat. Nature Reviews Microbiology, 11(1): 33-44.

Meer, R. R., et al (1991). Psychrotrophic Bacillus spp in fluid milk products: A review. Journal of Food Protection, 54: 969-979.

Minguita, A. P. S, et al (2015). Produção e caracterização de massas alimentícias a base de alimentos biofortificados: trigo, arroz polido, feijão carioca com casca. Santa Maria, Ciência rural, 45(10): 1895-1901.

Paiva, E P., et al (2009). Bacillus cereus e suas toxinas em alimentos. Higiene Alimentar, 23(70-171): 87-92.

Prado, S. P. T., et al. (2005). Extraneous materials and microorganisms contamination in flours for sale in Ribeirão Preto, SP. Revista Instituto Adolfo Lutz, 64(2): 237-244

Reyes, J. E., et al (2007). Prevalence of bacillus cereus in dried milk products use by Chilean School Feeding Program. Food Microbiology, 24: 1-6.

Rossi, E. M., et al (2012). Microbiological Contamination and Disinfection Procedures of Kitchen Sponges Used in Food Services. Food and Nutrition Sciences, 3: 975-980.

Rubio, M., \& Andres, G (2015). Ocorrência de Bacillus cereus em arroz cru vitaminado e cinética de multiplicação do patógeno no arroz cozido. 48 f. Dissertação (Mestrado em Ciência e Tecnologia de Alimentos) - Universidade Federal de Viçosa, 2015.

Sánchez, J, et al (2016). Bacillus cereus un patógeno importante en el control microbiológico de los alimentos. Revista Facultad Nacional de Salud Pública, 34(2): 230-242.

Sánchez, J. A., et al (2014). Direct detection of toxigenic Bacillus cereus in dietary complement for children and cassava starch. Medellín, Revista Colombiana de Química, 43(2): 5-9.

Scheuer, P. M., et al (2014). Effects of fat replacement on properties $\mathrm{f}$ whole wheat bread. Brazilian Journal of Pharmaceutical Sciences, 50(4): 703-712.

Senesi, S., \& Ghelardi, E. (2010). Production, secretion and biological activity of Bacillus cereus enterotoxins. Toxins, 2(7): 1690-1703.

Setlow P (2006). Spores of Bacillus subtilis: Their resistance to and killing by radiation, heat and chemicals. J. Applied Microbiology, 101(3): 514- 525.

Souza, J. R., et al (2015). Qualidade microbiológica da farinha de mandioca comercializada na região sudoeste da Bahia. Revista Brasileira de Produtos Agroindustriais, 17(2): 117-123.

Valerio F, et al (2012). Diversity of spore-forming bacteria and identification of Bacillus amyloliquefaciens as a species frequently associated with the ropy spoilage of bread. International Journal of Food Microbiology, 156(3): 278-285.

Van Der Auwera, G. A., Et Al (2007). Plasmid Exchanges Among Members Of The Bacillus Cereus Group In Foodstuffs. International Journal Food Microbiology, 113(2):164-72.

Wang, O. K. (1994). Kinetics of death of bacterial spores at elevated temperatures. Applied and Environmental Microbiology, 12(1): 451-454.

Webb, M.d, et al (2019). Risk presented to minimally processed chilled foods by psychrotrophic Bacillus cereus. Trends in Food Science \& Technology, 93: 94-105.

Wohlgemuth, S., \& Kämpfer, P. (2014). Bacteria | Bacterial Endospores, Editor(s): Carl A. Batt, Mary Lou Tortorello, Encyclopedia of Food Microbiology (Second Edition), Academic Press. 